\title{
Inhibition of Salmonella-induced IL-8 synthesis and expression of Hsp70 in enterocyte-like Caco-2 cells after exposure to non-starter lactobacilli ${ }^{2}$
}

\author{
Edina Nemeth ${ }^{a}$, Sana Fajdiga ${ }^{b}$, Joshua Malago ${ }^{c}$, Jos Koninkx ${ }^{d, *}$, Peter Tooten ${ }^{d}$, Jaap van Dijk ${ }^{d}$ \\ ${ }^{a}$ Central Food Research Institute, Herman Ottó út 15, H-1022 Budapest, Hungary \\ b Zootechnical Department, Biotechnical Faculty, University of Ljubljana, Groblje 3, 1230 Domžale, Slovenia \\ ${ }^{\mathrm{c}}$ Department of Pathology, Faculty of Veterinary Medicine, Sokoine University of Agriculture, P.O. Box 3203, Chuo Kikuu, Morogoro, Tanzania \\ d Department of Pathobiology, Division of Pathology, Faculty of Veterinary Medicine, Utrecht University, Yalelaan 1, \\ P.O. Box 80.158, 3508 TD Utrecht, The Netherlands
}

\begin{abstract}
Oral administration of lactobacilli as probiotics is gaining importance in the treatment of intestinal inflammations. We investigated the effect of non-starter lactobacilli Lactobacillus casei subsp casei 2756, Lactobacillus curvatus 2775, and Lactobacillus plantarum 2142 as well as their spent culture supernatants (SCS) on Salmonella enteritidis 857 growth, interleukin (IL)-8 and heat shock protein 70 (Hsp70) synthesis in undifferentiated crypt-like and differentiated villus-like Caco-2 cells. The cells were infected with graded numbers of non-starter lactobacilli or S. enteritidis 857 for $1 \mathrm{~h}$ and allowed to recover for $24 \mathrm{~h}$ or exposed to 200 bacteria/cell for $1 \mathrm{~h}$ and allowed to recover for different periods of time. In another experiment $S$. enteritidis 857 was first pre-treated with SCS-lactobacilli for $1 \mathrm{~h}$ before infecting the cells. The levels of IL-8 and Hsp70 were assessed using sandwich ELISA and immunostaining of Western blots, respectively. The effect of SCS-lactobacilli on S. enteritidis 857 growth was evaluated by agar plate diffusion test.

The non-starter lactobacilli induced a significant increase in the levels of both IL-8 and Hsp70. However, compared with the $S$. enteritidis 857 induced IL-8 synthesis, the levels of IL-8 induced by the lactobacilli at any equivalent bacterial number were far lower. After exposure of Caco- 2 cells to S. enteritidis 857 pre-treated with SCS-lactobacilli, it appeared that their SCS inhibited the S. enteritidis 857 growth and IL-8 synthesis and in addition induced the expression of Hsp70. The differences in response of crypt- and villus-like Caco-2 cells are merely a reflection of their differentiation status.

Our data suggest that the beneficial effect of non-starter lactobacilli to the intestinal inflammations might be associated with a decrease of the IL-8 levels. This effect could be mediated, at least in part, by the bacteria themselves or via a secreted antimicrobial product(s) either directly against the pathogens or indirectly through the synthesis of Hsp70.
\end{abstract}

(C) 2006 Elsevier B.V. All rights reserved.

Keywords: Non-starter lactobacilli; Salmonella enteritidis 857; Caco-2 cells; IL-8; Hsp70

\section{Introduction}

Lactobacillus casei subsp casei 2756, L. curvatus 2775, and L. plantarum 2142 are non-starter lactic acid bacteria that constitute considerably the microflora of mature cheese. Their inclusion in cheese manufacturing increases the level of free amino acids, peptides, and free fatty acids, which leads to enhanced flavour intensity and accelerates cheese ripening

\footnotetext{
This paper was presented at the 19th International ICFMH Symposium, Food Micro 2004, Potorož Slovenia, 12-16 September 2004.

* Corresponding author. Tel.: +31 30 2534307; fax: +31 302516853.

E-mail address: J.Koninkx@vet.uu.nl (J. Koninkx).
}

(Corsetti et al., 1998; Franklin and Sharpe, 1963; McSweeney et al., 1993). A considerable number of studies on non-starter lactic acid bacteria have focused on the effect of the microbes to the dairy products with little or no emphasis on the consumer. It has been shown however, that several Lactobacillus strains including L. casei subsp casei and L. plantarum exert a positive effect upon the consumer following oral administration. They improve the intestinal microbial balance, confer protection against potential enteropathogenic bacteria, and prevent and cure intestinal diseases (Fuller, 1989; Brassart and Schiffrin, 1997; Sugita and Togawa, 1994; Campieri et al., 2000; Gionchetti et al., 2000). These effects are mediated through production of various acids, hydrogen peroxide or bacteriocins, competition for nutrients or adhesion receptors, and anti-toxin 
actions. The lactobacilli have also been shown to stimulate the immune system and regulate cytokine production. They suppress synthesis of interleukin (IL)-8, transforming growth factor (TGF- $\beta$ ), and tumour necrosis factor (TNF- $\alpha$ ) by the intestinal epithelial cells (Reid et al., 2001; Wallace et al., 2003). Further, when administered intravenously, lactobacilli cultivation products induce the expression of a putative protective protein (Hsp70) in the rat heart that subsequently protects the heart against ischaemia and reperfusion tachyarrhythmia (Oxman et al., 2000). Since heat shock proteins suppress the synthesis of inflammatory cytokines like IL-8 (Malago et al., 2002) and lactobacilli induce these proteins in the rat heart, it is reasonable to suggest that lactobacilli also exert a beneficial effect upon the gut following oral uptake.

Many intestinal pathogens including S. enteritidis 857 induce an instant innate immune response following their invasion. This localized response involves the rapid expression and up-regulation of an array of pro-inflammatory cytokines, predominantly IL-8. The IL-8 attracts and directs neutrophil granulocytes to the site of inflammation, a response that is vital to the inflammatory diarrhoea caused by Salmonella infection (McCormick et al., 1998; Lee et al., 2000; Greenberg et al., 2002). Although this response is triggered to eliminate the pathogen, the persistent production of IL-8 often causes chronic inflammation that usually leads to tissue damage. Such an inflammation is characterised by high levels of IL- 8 and is observed in several intestinal disorders like ulcerative colitis, pouchitis, and Crohn's disease (Hecht and Savkovic, 1997; Hata et al., 2001). Interventions that decrease these levels have shown to significantly alleviate the conditions (Harig et al., 1989; O’Morain et al., 1982; Sanderson, 1997; Casellas et al., 1998). Although some lactobacilli inhibit IL-8 production by intestinal epithelial cells and some are implicated in the treatment and prevention of such intestinal diseases (Campieri et al., 2000; Gionchetti et al., 2000), the direct link between suppression of IL- 8 and alleviation of these diseases imparted by lactobacilli has not been established. Furthermore, the capacity of lactobacilli to induce Hsp70 that is known to inhibit IL-8 production by intestinal epithelial cells (Oxman et al., 2000; Malago et al., 2002), suggests a positive correlation between induction of Hsps, inhibition of IL-8 and improvement of intestinal disorders in the gut inhabited by lactobacilli. It is therefore compelling to hypothesize that part of the mechanism imparted by lactobacilli to the welfare of the intestinal epithelium involves regulation of IL-8 production either direct or indirect via induction of Hsp synthesis.

To gain more insight into the role of probiotics to the infected gut, we evaluated the positive effect of non-starter lactobacilli to the intestinal epithelium against the pathogenic $S$. enteritidis 857. This bacterium induces synthesis of IL- 8 and subsequent intestinal inflammations manifested as diarrhoeagenic illnesses in human (McCormick et al., 1998; Lee et al., 2000; Greenberg et al., 2002). We first assessed whether the non-starter lactobacilli L. casei subsp casei 2756, L. curvatus 2775, and L. plantarum 2142 and their microbial products can alter the S. enteritidis 857 induced IL-8 production. Secondly, we investigated whether these bacteria and their microbial products induce the expression of Hsp70 that can account for their beneficial effects to the gut. We used enterocyte-like Caco-2 cells, an in vitro model of the human intestinal epithelium that differentiate in culture and acquire characteristics both structurally and functionally of either crypt cells (5-day-old Caco-2 cells) or villus cells (19-day-old Caco-2 cells) of the small intestine (Koninkx et al., 1992; Koninkx, 1995; Ovelgönne et al., 2000; Malago et al., 2003).

\section{Materials and methods}

\subsection{Cell culture}

Human colon adenocarcinoma Caco-2 cells (ATCC HTB 37) were grown in Dulbecco modified Eagle medium (DMEM) supplemented with $1 \%(\mathrm{v} / \mathrm{v})$ non-essential amino acids, $10 \mathrm{mM}$ $\mathrm{NaHCO}_{3}, 1.7 \mathrm{mM}$ glutamine, $50 \mu \mathrm{g} / \mathrm{ml}$ gentamicin, $25 \mathrm{mM}$ Hepes (all Flow Laboratories, Amstelstad B.V., Amsterdam, The Netherlands), and 20\% (v/v) fetal calf serum (Bio Whittaker Europe, Verviers, Belgium). Supplemented culture medium devoid of gentamicin and fetal calf serum in the experiments is referred to as plain DMEM and devoid of fetal calf serum only as plain $\mathrm{DMEM}^{\text {genta }}$. Cell cultures were maintained at $37{ }^{\circ} \mathrm{C}$ in $95 \%$ air- $5 \% \mathrm{CO}_{2}$ in a humidified atmosphere with three cell culture medium changes per week. Cells were seeded at 40,000 cells $/ \mathrm{cm}^{2}$ in $25 \mathrm{~cm}^{2}$ tissue culture flasks (Greiner, Alphen a/d Rijn, The Netherlands) containing $5 \mathrm{ml}$ cell culture medium. 33 cell line passages ranging from the 5 th to the 37 th were used in this study.

\subsection{Bacterial strains}

DeMan, Rogosa, Sharpe (MRS) broth (Oxoid LTD., Basingstoke, Hampshire, England) (100 ml) was inoculated with $1 \mathrm{ml}$ of a stationary culture of the respective lactobacilli and grown for $24 \mathrm{~h}$ at $37{ }^{\circ} \mathrm{C}$. The bacterial culture was then centrifuged either for $15 \mathrm{~min}$ at $1500 \mathrm{~g}\left(20^{\circ} \mathrm{C}\right)$ to collect the lactobacilli or for $30 \mathrm{~min}$ at $10,000 \mathrm{~g}\left(4^{\circ} \mathrm{C}\right)$ to obtain spent culture supernatants (SCS). The collected lactobacilli were subsequently suspended in plain DMEM and serial dilutions were made to obtain different numbers of bacteria. The SCS were used to treat $S$. enteritidis 857 before infecting the cells and in agar plate diffusion tests.

One colony of $S$. enteritidis 857 grown on Luria-Bertani (LB) agar was inoculated into $10 \mathrm{ml} \mathrm{LB}$ broth. The inoculum was then grown overnight $(16 \mathrm{~h})$ with shaking $(200 \mathrm{rpm})$ at $37{ }^{\circ} \mathrm{C}$. The resulting bacterial suspension was inoculated into LB broth at 1:100 (v/v) followed by incubation with shaking (200 rpm) at $37^{\circ} \mathrm{C}$ for $2 \mathrm{~h}$ to obtain logarithmically growing bacteria. After this growth, the bacteria were collected by centrifugation $\left(15 \mathrm{~min} 1500 \mathrm{~g}\right.$ at $20^{\circ} \mathrm{C}$ ) and finally suspended in plain DMEM after or without various pre-treatments.

\subsection{Pre-treatment of $S$. enteritidis 857 by lactobacilli SCS}

Collected SCS from L. casei subsp casei 2756, L. curvatus 2775, and L. plantarum 2142 were sterilized through a sterile 
filter $(0.22 \mu \mathrm{m})$ and concentrated two-fold by freeze-drying. Since the $\mathrm{pH}$ of the MRS broth of a 24-hour culture of lactobacilli approximated 4.5, we used MRS broth controls with $\mathrm{pH}$ adjusted to 4.5 (lactic acid or $\mathrm{HCl}$ ). S. enteritidis 857 was pre-treated $\left(1 \mathrm{~h}\right.$ at $37^{\circ} \mathrm{C}$ ) by incubating in $25 \mathrm{ml} \mathrm{SCSLcc.2756,}$ SCSLc.2775, SCSLp.2142, MRS (pH 4.5 or 6.8) or plain DMEM (pH 4.5 or 7.4) and collected by centrifugation (15 min $1500 \mathrm{~g}$ at $37^{\circ} \mathrm{C}$ ). The bacteria were washed once with $10 \mathrm{ml}$ $0.01 \mathrm{M}$ phosphate-buffered saline (PBS) (0.01 $\mathrm{M} \mathrm{Na}_{2} \mathrm{HPO}_{4}$, $0.01 \mathrm{M} \mathrm{NaH}_{2} \mathrm{PO}_{4}, 0.9 \%(\mathrm{w} / \mathrm{v}) \mathrm{NaCl}$ ), $\mathrm{pH} 7.3$ and finally resuspended in plain DMEM ( $\mathrm{pH} 7.3$ ) before infecting the cells.

\subsection{Exposure of the Caco-2 cells to lactobacilli or S. enteritidis 857}

In one set of experiments, Caco-2 cells were exposed to graded numbers of L. casei subsp casei 2756, L. curvatus 2775 or L. plantarum 2142 (0-200 bacteria/cell) for $1 \mathrm{~h}$. The cells were then allowed to recover for $24 \mathrm{~h}$. In another set of experiments Caco-2 cells were infected with 200 bacteria/cell (L. casei subsp casei 2756, L. curvatus 2775, L. plantarum 2142 or $S$. enteritidis 857 ) and allowed to recover for $2,4,6,8$, 16 , or $24 \mathrm{~h}$. In the final set of experiments, the cells were infected with SCS pre-treated S. enteritidis 857 (100 Se/cell, $1 \mathrm{~h})$. In this case too the subsequent recovery period lasted for 2 , $4,6,8,16$, or $24 \mathrm{~h}$. In all experiments termination of the exposure to bacteria took place by washing the cells twice with $5 \mathrm{ml}$ plain DMEM ${ }^{\text {genta }}$.

\subsection{Collection of the cell culture medium and the Caco-2 cells}

After collecting the cell culture medium (10 min $600 \mathrm{~g}$ at $4{ }^{\circ} \mathrm{C}$ ), the cell monolayers were rinsed twice with $5 \mathrm{ml} \mathrm{PBS}$ $\left(37^{\circ} \mathrm{C}\right)$. The monolayers were then incubated for $30 \mathrm{~min}$ at $37^{\circ} \mathrm{C}$ with $5 \mathrm{ml}$ transfer medium, pH $7.3\left(8 \mathrm{~g} / 1 \mathrm{NaCl}, 0.2 \mathrm{~g} / 1 \mathrm{KH}_{2} \mathrm{PO}_{4}\right.$, $\left.0.2 \mathrm{~g} / 1 \mathrm{Na}_{2} \mathrm{EDTA} \cdot 2 \mathrm{H}_{2} \mathrm{O}\right)$. Subsequently, the dispersed cells were collected in tubes and washed twice with $10 \mathrm{ml} \mathrm{PBS}\left(0^{\circ} \mathrm{C}\right)$. The washing procedure involved centrifugation $(10 \mathrm{~min} 300 \mathrm{~g}$ at $4{ }^{\circ} \mathrm{C}$ ) and discarding of supernatants. After the last washing step, the cells were collected by centrifugation $\left(10 \mathrm{~min} 600 \mathrm{~g}\right.$ at $\left.4{ }^{\circ} \mathrm{C}\right)$. The collected cell culture supernatants and the cells were then stored at $-70{ }^{\circ} \mathrm{C}$ until being analysed.

\subsection{Inhibition of S. enteritidis 857 growth by lactobacilli SCS}

The effect of SCS from L. casei subsp casei 2756, L. curvatus 2775, and L. plantarum 2142, MRS and plain DMEM on the growth of $S$. enteritidis 857 was assessed by agar plate diffusion test. Sterilized nutrient agar [1 g/l lab lemco broth, $2 \mathrm{~g} / 1$ yeast extract, $5 \mathrm{~g} / 1$ pepton water, $15 \mathrm{~g} / 1$ agar bacteriological (all Oxoid), $5 \mathrm{~g} / \mathrm{l} \mathrm{NaCl}]$ (pH 7.4) was dispensed in petri dishes. Two wells per dish were made using a 14-mmdiameter gel punch. A total volume of $450 \mu \mathrm{l}(3 \times 150 \mu \mathrm{l})$ from each sample was added to the respective well. To speed up the diffusion, the dishes were incubated $\left(50^{\circ} \mathrm{C}\right)$ after each addition of $150 \mu \mathrm{l}$. From the stationary growth phase of $S$. enteritidis $857,500 \mu \mathrm{l}$ of $10^{4}$ or $10^{5} \mathrm{CFU} / \mathrm{ml}$ was added to $5 \mathrm{ml} \mathrm{MRS}$ broth
(45 ${ }^{\circ} \mathrm{C}$ ) containing $0.7 \%$ agar. The agar was rapidly dispersed and poured into the dishes, which were then incubated overnight at $37^{\circ} \mathrm{C}$ before assessment of the diameters of the inhibition zones.

\subsection{Western blot analysis}

Distilled water $\left(4^{\circ} \mathrm{C}\right)$ was added to the collected Caco- 2 cells ( $0.4 \mathrm{ml}$ for crypt- and $1.0 \mathrm{ml}$ for villus-like) and the mixture was sonicated $\left(0{ }^{\circ} \mathrm{C}, 30 \mathrm{~s}\right.$ at an amplitude of $24 \mu \mathrm{m}$ amplitude $)$ with an MSE Soniprep 150 (Beun de Ronde BV, Abcoude, The Netherlands). The protein content of the resulting sonicates was determined (Smith et al., 1985) and found to be equal in all samples. One-third of the volume of loading buffer $(3 \times$ concentrated) [125 mM Tris-(hydroxymethyl)aminomethane- $\mathrm{HCl}, 4 \%$ sodium dodecyl sulfate (SDS), 10\% $\beta$-mercaptoethanol, 20\% glycerol, and $0.0015 \%$ bromophenolblue, $\mathrm{pH} 6.8$ ] was added to the protein samples and the mixture was heated $\left(95^{\circ} \mathrm{C}, 5 \mathrm{~min}\right)$. Equal amounts of proteins $(10 \mu \mathrm{g})$ loaded on the slots of $10 \%$ SDS polyacrylamide gels were separated. A protein ladder (BioRad Laboratories, California, USA) was loaded as a molecular weight marker. The proteins were then transferred to Immobilon-P polyvinylidene difluoride membrane following the recommendations of the manufacturer (Millipore, Bedford, USA). Staining with Ponceau Red stain confirmed the protein transfer. Blocking of the non-specific binding sites on the membrane occurred by incubating the membrane for $1 \mathrm{~h}$ with $10 \mathrm{ml}$ of blocking solution $(0.1 \%$ Tween/PBS, pH 7.3 containing 5\% Boehringer blocking agent) (Amersham Pharmacia Biotech, Buckinghamshire, UK). After a washing procedure with $50 \mathrm{ml}$ of washing buffer $(0.1 \%$ Tween/PBS, $\mathrm{pH} 7.3)$, which consisted of two quick washes followed by three additional ones $(1 \times 15 \mathrm{~min}, 2 \times 5 \mathrm{~min})$ the membrane was incubated for $1 \mathrm{~h}$ with $2.5 \mu \mathrm{g}$ of mouse anti-Hsp70 monoclonal antibody (SPA-810) (Stressgen Biotechnologies Corporation, Victoria, British Columbia, Canada) in $5 \mathrm{ml}$ blocking solution. After repeating the above washing procedure, the blots were incubated for $1 \mathrm{~h}$ with $5 \mu \mathrm{g}$ of goat anti-mouse $\mathrm{IgG}$ alkaline phosphatase secondary antibody (SAB-101) (Stressgen) in $10 \mathrm{ml}$ blocking solution ( $0.1 \%$ Tween/PBS, $\mathrm{pH} 7.3)$ containing $0.5 \%$ Boehringer blocking agent. The washing procedure was repeated again and the blots were incubated for $5 \mathrm{~min}$ in $10 \mathrm{ml}$ alkaline phosphatase detection buffer $(0.1 \mathrm{M}$ Tris- $\mathrm{HCl}, 0.1 \mathrm{M}$ $\mathrm{NaCl}, 5 \mathrm{mM} \mathrm{MgCl} 2 \cdot 6 \mathrm{H}_{2} \mathrm{O}$, pH 9.5) containing $35 \mu \mathrm{l}$ nitroblue tetrazolium chloride $(100 \mathrm{mg} / \mathrm{ml})$ (product number 1383213 ) and $35 \mu \mathrm{l}$ 5-bromo-4-chloro-3-indoyl-phosphate $(50 \mathrm{mg} / \mathrm{ml})$ (product number 1383221) (both from Roche Diagnostics GmbH, Mannheim, Germany).

\subsection{Determination of IL-8 secretion by sandwich ELISA}

IL-8 concentrations were assayed using the IL-8 Cytosets ${ }^{\text {TM }}$ antibody pair kit containing matched, pre-titered and fully optimized capture and detection antibodies, recombinant standard and streptavidin-horseradish peroxidase (catalog number CHC1304) (Biosource Europe S.A., Nivelles, Belgium). The assay was done according to the manufacturer's specifications. 


\subsection{Statistical analysis}

Statistical significance between the mean values of control, L. casei subsp casei 2756 , L. curvatus 2775 , L. plantarum 2142, lactobacilli SCS and $S$. enteritidis 857 exposed cells was assessed by one-way analysis of variance (ANOVA) with comparison of means. Differences were considered significant at $95 \%$ confidence interval using the Student's $T$-test.

\section{Results}

\subsection{IL-8 production by Caco-2 cells exposed to non-starter} lactobacilli, or $S$. enteritidis 857

After exposure of the cells for $1 \mathrm{~h}$ to graded numbers of L. casei subsp casei 2756, L. curvatus 2775 , and L. plantarum $2142(1,2,10,20,100$, and 200 bacteria/cell), a linear dosedependent production of IL-8 could be established (Fig. 1).
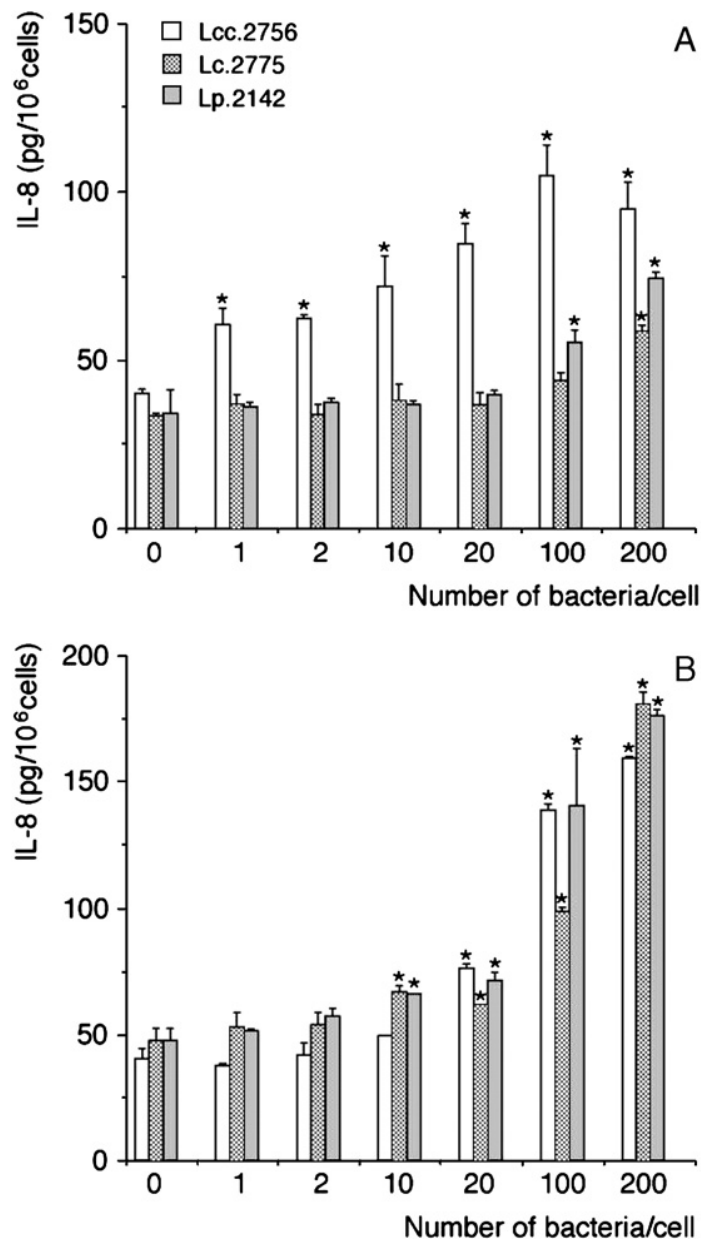

Fig. 1. Dose-dependent induction of IL- 8 synthesis in Caco-2 cells after exposure to non-starter lactobacilli. Crypt- (A) or villus-like (B) Caco-2 cells were exposed to $0,1,2,10,20,100$, or 200 bacteria/cell for $1 \mathrm{~h}$ in plain DMEM. After $24 \mathrm{~h}$ of recovery in plain $\mathrm{DMEM}^{\text {genta }}$, the cell culture medium was collected and IL-8 levels were measured using ELISA. The results are expressed as pg IL- $8 / 10^{6}$ cells. The IL- 8 levels were determined using two cell passages and triplicate cultures per passage. Significant differences $\left({ }^{*} p<0.05\right)$ between the IL-8 levels of cells exposed to non-starter lactobacilli and control cells are indicated.
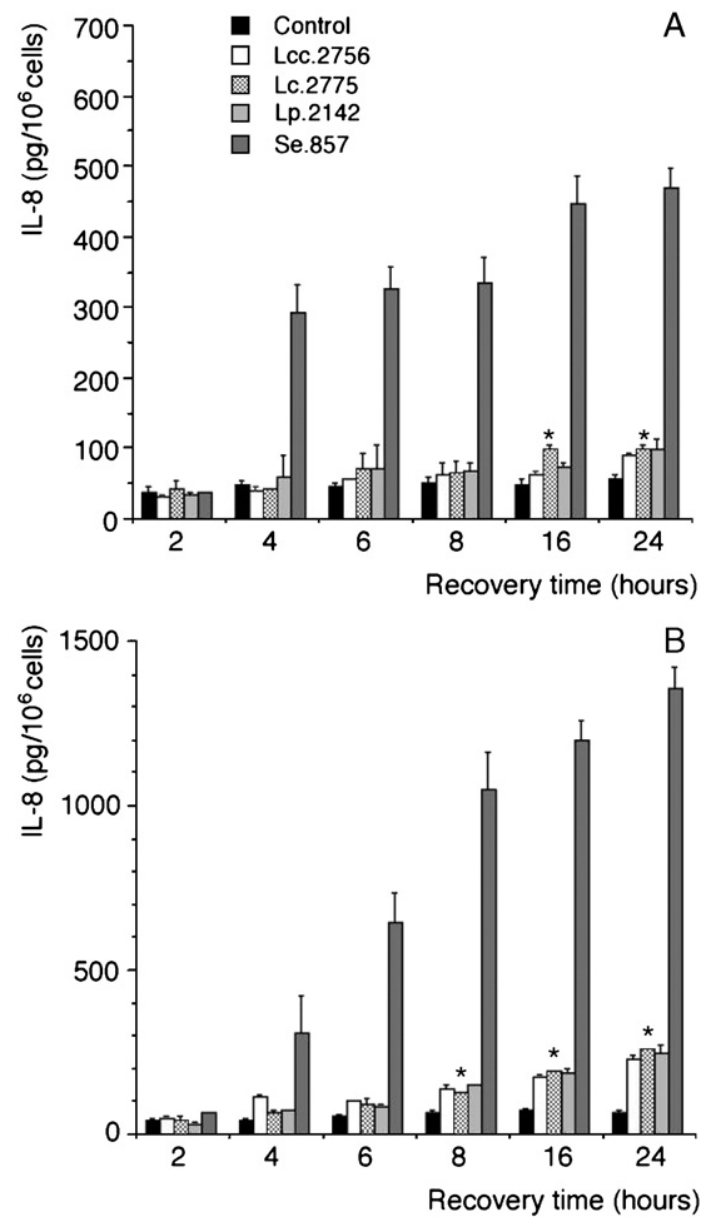

Fig. 2. Time-course induction of IL- 8 synthesis by non-starter lactobacilli and $S$. enteritidis 857 in Caco-2 cells. Crypt- (A) and villus-like (B) Caco-2 cells were exposed to non-starter lactobacilli or $S$. enteritidis 857 (200 bacteria/cell) for $1 \mathrm{~h}$ in plain DMEM. After recovery for $2,4,6,8,16$, or $24 \mathrm{~h}$ in plain DMEM genta, the culture medium was collected and IL- 8 levels were measured using ELISA. The results are expressed as pg IL- $8 / 10^{6}$ cells. IL- 8 secretion was determined using two cell passages and triplicate cultures per passage. Significant differences $\left({ }^{*} p<0.05\right)$ between the IL- 8 levels of cells exposed to non-starter lactobacilli and control cells are indicated.

Already on exposure to low numbers of $L$. casei subsp casei 2756 ( 1 bacteria/cell) a significant increase in the levels of IL-8 synthesis above those of the control cells was observed in crypt-like Caco-2 cells (Fig. 1A). This increase reached the highest values after incubation with 100 bacteria/cell. By contrast, low numbers of $L$. curvatus 2775 and L. plantarum 2142 (1-20 bacteria/cell) only slightly affected the IL-8 synthesis while high numbers (100-200 bacteria/cell) induced a significant increase. The levels of IL8 induced by $L$. case $i$ subsp casei 2756 in these crypt-like Caco- 2 cells were significantly higher than those of L. curvatus 2775 and L. plantarum 2142 at any concentration tested (Fig. 1A). In villuslike cells (Fig. 1B) low numbers of non-starter lactobacilli had little or no effect at all on IL-8 production, whereas higher numbers induced a significant dose-dependent production of IL-8. The induction was highest when the cells were exposed to 200 bacteria/ cell.

Fig. 2 clearly shows a linear time-course production of IL- 8 by Caco-2 cells exposed to L. casei subsp casei 2756, L. curvatus 

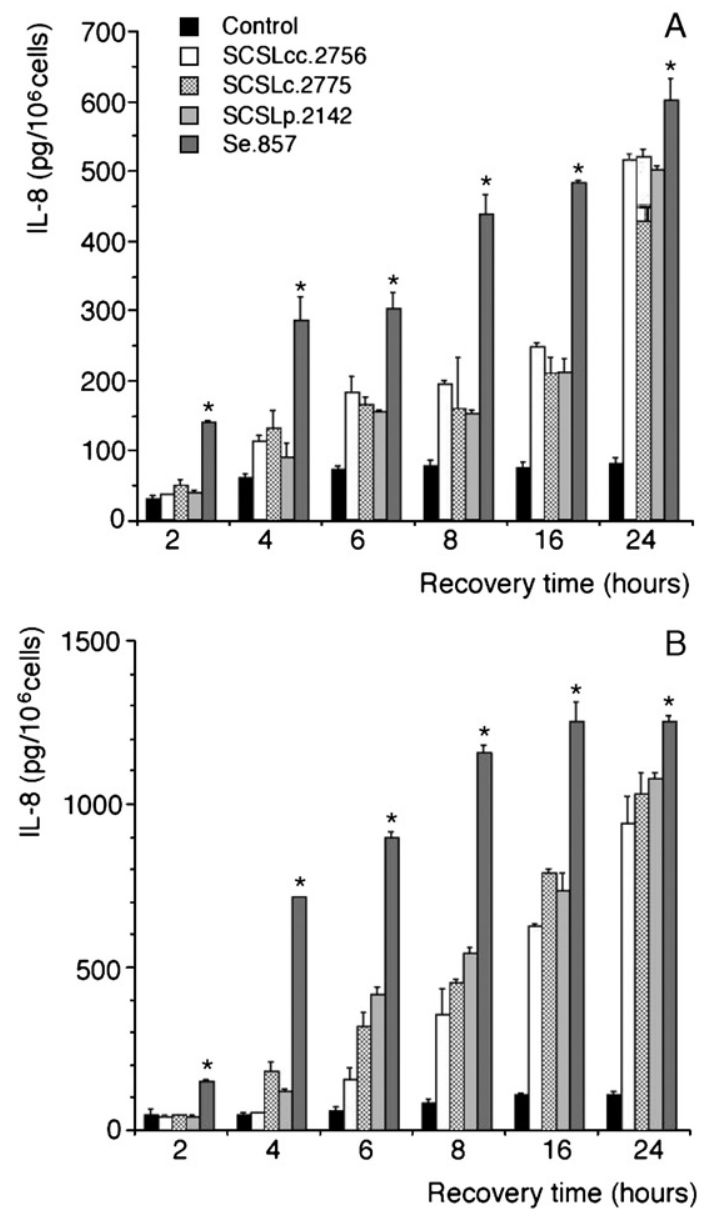

Fig. 3. Inhibition of $S$. enteritidis 857 -induced IL-8 synthesis by SCS from nonstarter lactobacilli in Caco-2 cells. Crypt- (A) and villus-like (B) Caco-2 cells were exposed for $1 \mathrm{~h}$ to $S$. enteritidis 857 (100 bacteria/cell) in plain DMEM. Before exposure, these bacteria were pre-treated in non-starter lactobacilli SCS, or plain DMEM for $1 \mathrm{~h}$. After a recovery period of 2, 4, 6, 8, 16, or $24 \mathrm{~h}$ in plain DMEM $^{\text {genta }}$, the culture medium was collected and IL-8 levels were measured using ELISA. The results are expressed as pg IL-8/10 ${ }^{6}$ cells. IL-8 secretion was established using 2 cell passages and triplicate cultures per passage. Significant differences $\left({ }^{*} p<0.05\right)$ between the IL-8 levels of cells exposed to $S$. enteritidis 857 pre-treated with plain DMEM and those pre-treated with SCS from nonstarter lactobacilli are indicated.

2775, L. plantarum 2142, or S. enteritidis 857 (200 bacteria/cell). Compared with the unexposed Caco-2 cells exposure to the nonstarter lactobacilli resulted in a gradual increase of the IL-8 levels that became significant after $16 \mathrm{~h}$ of recovery in crypt-like cells and after $8 \mathrm{~h}$ in villus-like cells. Compared to control cells and cells exposed to $L$. casei subsp casei 2756 , L. curvatus 2775 , and L. plantarum 2142, the levels of IL-8 induced by $S$. enteritidis 857 in both crypt- (Fig. 2A) and villus-like cells (Fig. 2B) were far higher at any equivalent bacterial numbers. The highest IL- 8 levels appeared to be present in cells recovering for $24 \mathrm{~h}$ following S. enteritidis 857 infection.

3.2. Inhibition of Salmonella-induced IL-8 production by nonstarter lactobacilli SCS in Caco-2 cells

To investigate the effect of SCS from $L$. casei subsp casei 2756, L. curvatus 2775, or L. plantarum 2142 on S. enteritidis
Table 1

Inhibition of S. enteritidis 857 growth by SCS from non-starter lactobacilli

\begin{tabular}{lc}
\hline Treatment & Width of the inhibition zone $(\mathrm{mm})$ \\
\hline Plain DMEM pH 7.4 (control) & $3.0 \pm 1.2$ \\
MRS broth pH 6.8 (control) & $2.7 \pm 0.8$ \\
Plain DMEM pH 4.5 & $9.8 \pm 2.3^{\mathrm{a}}$ \\
MRS broth pH 4.5 & $8.3 \pm 1.7^{\mathrm{a}}$ \\
SCS Lactobacillus casei subsp casei 2756 & $16.3 \pm 0.3^{\mathrm{a}, \mathrm{b}}$ \\
SCS Lactobacillus curvatus 2775 & $13.8 \pm 0.8^{\mathrm{a}, \mathrm{b}}$ \\
SCS Lactobacillus plantarum 2142 & $15.9 \pm 1.0^{\mathrm{a}, \mathrm{b}}$ \\
\hline
\end{tabular}

Spent culture supernatants (SCS) from non-starter lactobacilli were loaded in nutrient agar holes followed by pouring of Salmonella enteritidis 857 suspension. After overnight incubation at $37^{\circ} \mathrm{C}$, growth inhibition rings were measured around the holes. Two experiments were performed to determine the

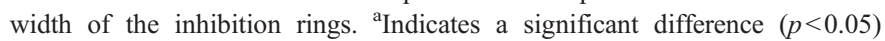
between the inhibition zones for holes containing plain DMEM, pH 4.5, MRS broth $\mathrm{pH} 4.5$ or SCS and the controls and between those containing SCS and plain DMEM or MRS broth, $\mathrm{pH} 4.5$.

857-induced production of IL-8, the Caco-2 cells were exposed for $1 \mathrm{~h}$ to pre-treated $S$. enteritidis 857 (100 Se/cell). The pretreatment involved a 1-hour incubation period of the pathogen with non-starter lactobacilli SCS. As indicated in Fig. 3A, B a significant decrease in S. enteritidis 857 -induced IL-8 synthesis was observed when the Caco-2 cells were infected with S. enteritidis 857 pre-treated with SCSLcc.2756, SCSLc.2775, or SCSLp.2142. The decrease of the IL-8 levels, which was already obvious after $4 \mathrm{~h}$, could be observed throughout the recovery period $(2-24 \mathrm{~h})$ in both crypt- and villus-like cells. At this time point the IL-8 levels were about 3 - to 5 -fold lower than in cells exposed to $S$. enteritidis 857 pre-treated with plain DMEM, $\mathrm{pH} 4.5$ or 7.4 , respectively (untreated pathogen) (Fig. 3A).
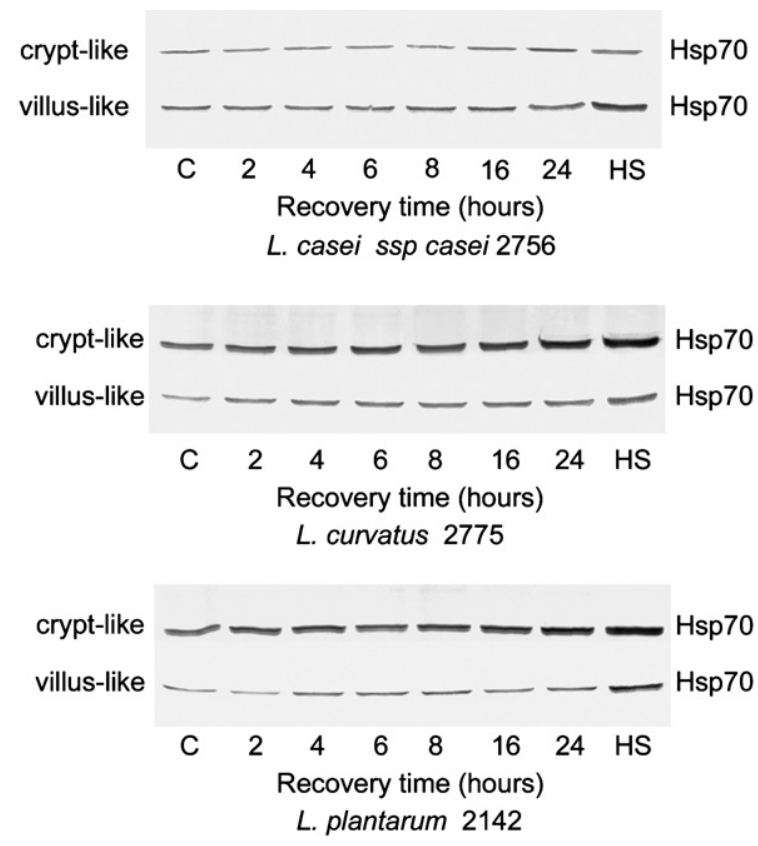

Fig. 4. Expression of Hsp70 in Caco-2 cells after exposure to non-starter lactobacilli. Crypt- or villus-like Caco-2 cells were exposed to non-starter lactobacilli for $1 \mathrm{~h}$. After 2-24 h of recovery in plain DMEM ${ }^{\text {genta }}$, cells were processed for Western blotting and immunostaining. [C: levels of Hsp70 in control Caco-2 cells; HS: levels of Hsp70 in heat shocked cells $\left(1 \mathrm{~h}\right.$ at $42{ }^{\circ} \mathrm{C} ; 6 \mathrm{~h}$ recovery at $\left.\left.37^{\circ} \mathrm{C}\right)\right]$. 

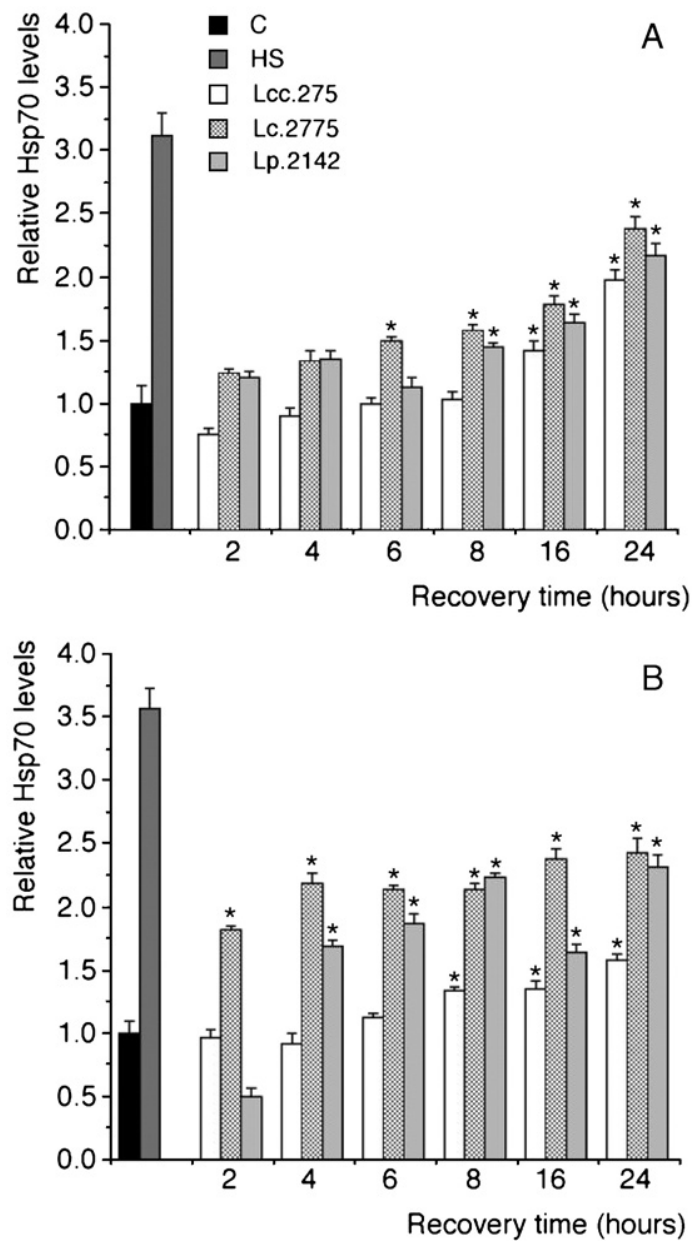

Fig. 5. Relative Hsp70 levels in Caco-2 cells after exposure to non-starter lactobacilli. Crypt- (A) or villus-like (B) Caco-2 cells were exposed to nonstarter lactobacilli for $1 \mathrm{~h}$. After $2-24 \mathrm{~h}$ of recovery in plain DMEM ${ }^{\text {genta }}$ the relative levels of Hsp70 were established using 2 cell passages and triplicate cultures per passage. Significant differences $\left({ }^{*} p<0.05\right)$ between the Hsp70 levels of cells exposed to non-starter lactobacilli and control cells are indicated.

Exposure of the Caco-2 cells to $S$. enteritidis 857 pre-treated with MRS broth (pH 4.5) lowered the IL-8 levels. However, compared to the SCS treatment the IL-8 decreasing activity of MRS broth appeared to be much smaller (data not shown).

The IL-8 levels of both crypt- and villus-like cells exposed to SCSLcc.2756, SCSLc.2775, and SCSLp.2142 pre-treated salmonellae steadily increased in a time-dependent manner. Despite this increase, a significant difference remained present after $24 \mathrm{~h}$ of recovery between these cells and those infected with the untreated pathogen (Fig. 3).

\subsection{Growth inhibition of S. enteritidis 857 by SCS from non- starter lactobacilli}

The results of the agar plate diffusion tests, which are presented in Table 1, clearly showed that the SCS from non-starter lactobacilli inhibited the growth of $S$. enteritidis 857 . Although $\mathrm{pH}$ interfered significantly with $S$. enteritidis 857 growth, the width of the inhibition rings displayed by MRS broth and plain DMEM were significantly smaller than the SCS-induced ones.

\subsection{Expression of Hsp70 in Caco-2 cells after exposure to non- starter lactobacilli}

Since the expression of Hsp70 is associated with the protection of intestinal epithelial cells, we investigated whether the non-starter lactobacilli could modify the expression of Hsp70 in Caco-2 cells. Exposure of the cells for $1 \mathrm{~h}$ to the nonstarter lactobacilli resulted in a time-dependent increase of Hsp70 levels in both crypt- and villus-like Caco-2 cells (Fig. 4). At $24 \mathrm{~h}$ after recovery from exposure to $L$. casei subsp casei 2756, L. curvatus 2775 , or L. plantarum 2142, the relative levels of expression of Hsp70 in these cells amounted to twothird of the levels in heat shocked cells (Fig. 5A, B).

\subsection{Expression of Hsp70 in Caco-2 cells after exposure to SCS-treated S. enteritidis 857}

We also investigated the effect of SCS from $L$. casei subsp casei 2756, L. curvatus 2775, or L. plantarum 2142 on the expression of Hsp70 in Caco-2 cells. When the cells were exposed for $1 \mathrm{~h}$ to $S$. enteritidis 857 pre-treated with SCS from non-starter lactobacilli, the induction of the expression of Hsp70 could be observed in both crypt- and villus-like Caco-2 cells (Fig. 6). In the crypt-like cells the relative level of expression appeared to be time-dependent and to reach their highest levels 24 and $48 \mathrm{~h}$ after recovery from exposure (Fig. 7A). At these time points the relative level of expression of Hsp70 matched the level of expression of this protein in heat shocked cells. The expression of Hsp70 in the villus-like cells was different. At 2,
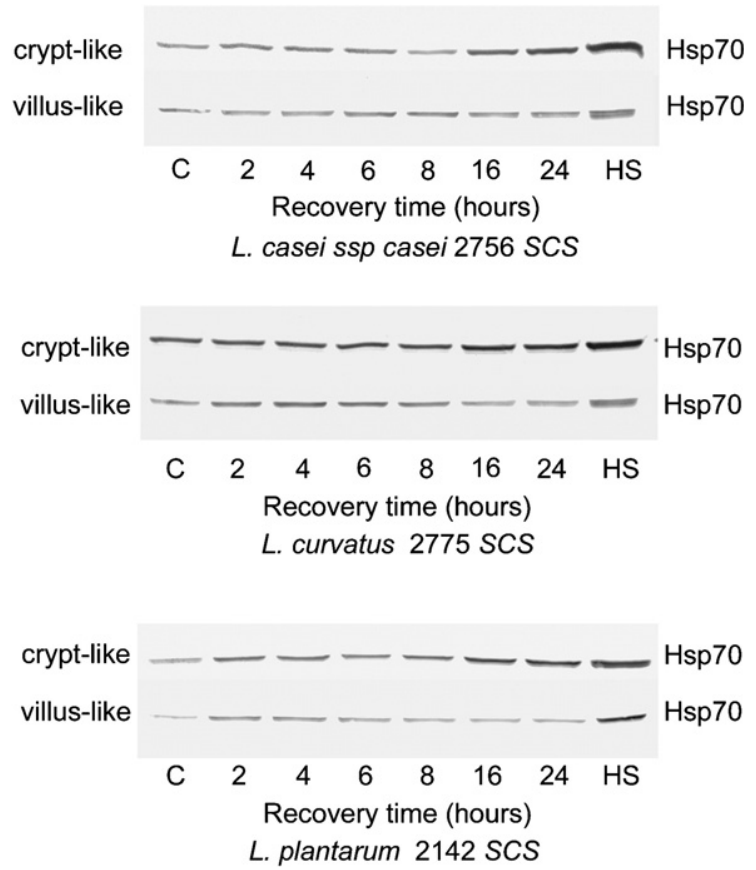

Fig. 6. Expression of Hsp70 in Caco-2 cells after incubation with S. enteritidis 857 pre-treated with SCS from non-starter lactobacilli. Crypt- or villus-like Caco-2 cells were exposed to SCS from non-starter lactobacilli for $1 \mathrm{~h}$. After $2-$ $24 \mathrm{~h}$ of recovery in plain $\mathrm{DMEM}^{\text {genta }}$, cells were processed for Western blotting and immunostaining. [C: levels of Hsp70 in control Caco-2 cells; HS: levels of Hsp70 in heat shocked cells $\left(1 \mathrm{~h}\right.$ at $42^{\circ} \mathrm{C} ; 6 \mathrm{~h}$ recovery at $\left.\left.37^{\circ} \mathrm{C}\right)\right]$. 

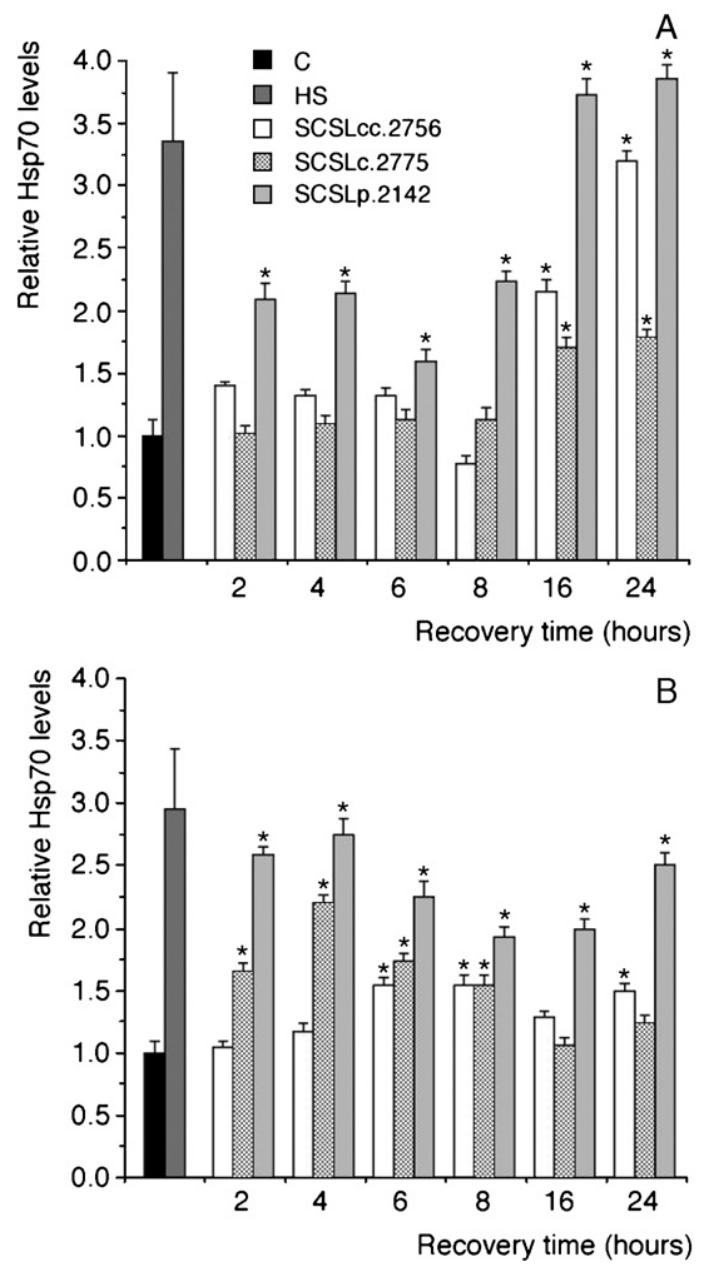

Fig. 7. Relative Hsp70 levels in Caco-2 cells after incubation with S. enteritidis 857 pre-treated with SCS from non-starter lactobacilli. Crypt- (A) or villus-like (B) Caco-2 cells were exposed to SCS from non-starter lactobacilli for $1 \mathrm{~h}$. After 2-24 h of recovery in plain DMEM ${ }^{\text {genta }}$ the relative levels of Hsp70 were established using 2 cell passages and triplicate cultures per passage. Significant differences $\left({ }^{*} p<0.05\right)$ between the Hsp70 levels of cells exposed to S. enteritidis 857 pre-treated with SCS from non-starter lactobacilli and control cells are indicated.

4, 6 and $8 \mathrm{~h}$ after recovery an initial significant increase in the relative expression of Hsp70 could be observed in the villus-like cells exposed to $S$. enteritidis 857 pre-treated in SCS from L. casei subsp casei 2756, L. curvatus 2775 and L. plantarum 2142 (Fig. 7B). After this Hsp70 peak the levels of Hsp70 started to decline, but remained higher than those of the control cells $\left(37^{\circ} \mathrm{C}\right)$. Compared with the levels of Hsp70 in Caco-2 cells exposed to $S$. enteritidis 857 there was no change in the induction of Hsp70 expression when cells were incubated with S. enteritidis 857 pre-treated with MRS broth ( $\mathrm{pH} 4.5$ or 6.8 ) or plain DMEM (pH 4.5 or 7.4) (data not shown).

\section{Discussion}

L. casei subsp casei 2756, L. curvatus 2775, and L. plantarum 2142 are among the most frequently used bacteria in cheese to enhance flavour intensity and to accelerate cheese ripening (Corsetti et al., 1998; Franklin and Sharpe, 1963;
McSweeney et al., 1993). Their effect upon the host is not clearly understood. However, there is a strong evidence for positive effects in intestinal disorders following oral administration of selected strains of Lactobacillus (Schrezenmeir and de Vrese, 2001). They condition the level of activation of the mucosal immune response and play a vital role in driving the mucosal inflammation in genetically susceptible individuals. This activation involves the expression and secretion of various inflammatory cytokines, including the chemoattractant IL-8 (Hata et al., 2001), at constitutive levels that are considered insignificant to alter the normal microenvironment (Coconnier et al., 2000). Consistently, this study shows that the probiotics $L$. casei subsp casei 2756 , L. curvatus 2775 , and L. plantarum 2142 induce very low levels of IL-8 when compared with those induced by the pathogenic S. enteritidis 857 (Fig. 2). Indeed, the highest levels induced after $24 \mathrm{~h}$ were just slightly higher than those of control cells, alluding that they might be within the range of constitutive expression responsible for normal immune surveillance.

The IL-8 production is an instant local defensive inflammatory response against various potentially harmful intestinal pathogens. IL-8 is pivotal to and governs the progress of most local intestinal inflammations. It attracts and activates neutrophils at the site of infection to combat the pathogens. Persistent secretion of IL-8 that leads to neutrophil infiltration often causes chronic inflammation and may subsequently culminate into epithelial cell damage (McCafferty and Zeitlin, 1989). These effects can be avoided by down-regulation of IL-8 synthesis at some stages when the inflammation is resolved. In fact, chronic inflammations characterised by high levels of IL-8 such as inflammatory bowel diseases are cured by interventions that decrease the levels of IL-8. The actual mechanism of Lactobacillus probiotics used in the treatment of such disorders is enigmatic. Our data in this study clearly indicate that exposure of enterocyte-like Caco-2 cells to S. enteritidis 857 pre-treated with the SCS of the non-starter lactobacilli L. casei subsp casei 2756, L. curvatus 2775 or L. plantarum 2142 significantly inhibits the Salmonellainduced IL-8 production (Fig. 3). Pre-treatment of S. enteritidis 857 with non-starter lactobacilli SCS (pH 4.5) most likely dissociates the flagella. Since flagellin is an important stimulus for epithelial IL-8 secretion, because of its ability to activate Toll-like receptor 5 (Huang et al., 2004), these partly aflagellated bacteria do not equally synthesise effectively IL-8 as the flagellated ones. Part of the IL-8 decreasing activity appeared to be $\mathrm{pH}$-dependent, because cells pre-treated with MRS broth at pH 4.5 significantly lowered the IL-8 levels. However, compared to the SCS non-starter lactobacilli treatment the effect on the IL8 levels was much smaller (data not shown). These results are consistent with the observation that SCS from $L$. acidophilus inhibit Salmonella enterica typhymurium-induced IL-8 production by Caco-2 cells (Coconnier et al., 2000). The L. acidophilus SCS was found to contain antibacterial components active against Salmonella infecting the cultured human intestinal Caco-2 cells. This activity appeared to be independent of lactic acid production (Bernet-Camard et al., 1997). Recently, several strains of Lactobacillus rhamnosus and Lactobacillus delbrueckii were also observed to down-regulate IL-8 production by HT-29 cells, an 
intestinal epithelial cell line (Wallace et al., 2003). Together with our findings, it appears that inhibition of IL-8 production may be part of the mechanism by which lactobacilli impart their welfare to the gut. This could explain their ability to treat intestinal disorders associated with high levels of IL-8. Indeed, beyond improving the quality of the cheese, L. casei subsp casei 2756, L. curvatus 2775 , and $L$. plantarum 2142 could benefit the gut against potential pathogens and their effects.

The expression of Hsp70 by intestinal epithelial cells exposed to Lactobacillus ssp or their cultivation products had not been studied. An extensive experimental investigation conducted in the animal models showed that Lactobacillus cultivation products produced a marked long-term protection against ischaemised rat heart. This effect was attributed to an activation of the cellular defence system manifested by overexpression of Hsp70 (Oxman et al., 2000). We previously demonstrated the ability of enterocyte-like Caco-2 cells to produce the protective Hsp70 under various conditions (Ovelgönne et al., 2000; Malago et al., 2003). In this study, we report that $L$. casei subsp casei 2756, L. curvatus 2775, and L. plantarum 2142 and their SCS are capable of inducing Hsp70 expression in the Caco-2 cells (Figs. 4 and 5). This response is specific to the bacteria and their SCS since the MRS broth or variations in $\mathrm{pH}$ could not induce the Hsp70 expression. Because the production of Hsp70 is a protective response (Malago et al., 2002; Ovelgönne et al., 2000), we suggest that one mechanism for the beneficial attributes of the non-starter lactobacilli is the ability to induce the expression of Hsp70 by the bacteria and their antimicrobial products. The induced Hsp70 could function in the stabilisation of the cytoskeleton of intestinal epithelial cells after being distorted during adhesion and invasion by Salmonella (Jepson et al., 1995, 1996). In turn, this could impede further Salmonella invasion. Furthermore, since SCS from L. casei GG hamper invasion of Caco-2 cells by S. typhimurium C5 without altering their viability (Hudault et al., 1997), expression of Hsp70 could protect cells against the viable intracellular bacteria and/or the pro-inflammatory cytokines they produce. It has been suggested that the beneficial effects of probiotics in host defence against infection include anti-inflammatory properties. These properties involve signalling with the gastrointestinal epithelium and with mucosal regulatory T-cells (Shanahan, 2000). Probiotics may also counterbalance epithelial responses to invasive bacteria by regulating the cytokine transcription factors (Neish et al., 2000). In the latter mechanism of action, Hsps might play an essential role through their ability to interfere with cytokine production in intestinal epithelial cells (Malago et al., 2002).

The exact way in which probiotics may achieve their effects is still uncertain. However, lactobacilli are capable of preventing the adherence, establishment, replication, and pathogenic action of specific enteropathogens (Saavedra, 1995). A number of mechanisms have been proposed, such as decreasing the luminal $\mathrm{pH}$ via the production of short chain fatty acids, rendering specific nutrients unavailable to pathogens, and/or producing specific inhibitory compounds such as bacteriocins (Sanders, 1993). The produced bacteriocins act bactericidally against bacteria (Klaenhammer, 1993). It appears from several studies that the underlying mechanism for the beneficial effect of Lactobacillus probiotics is mainly mediated via their microbial products rather than the bacteria themselves (Coconnier et al., 2000; Hudault et al., 1997). In this study we have shown that the non-starter lactobacilli commonly used in cheese industry, L. casei subsp casei 2756, L. curvatus 2775 , and L. plantarum 2142 or their cultivation products, inhibit Salmonella-induced IL-8 production and induce expression of Hsp70 in enterocytelike Caco-2 cells. With sketchy comparable data, to the best of our knowledge, this study is the first to report the potential of these non-starter lactobacilli to interfere with the IL-8 and Hsp70 synthesis in the intestinal epithelial Caco-2 cells. We suggest that these effects are part of the yet unexplored mechanism involved in the beneficial effect of probiotics to the gut.

\section{Acknowledgement}

This research was supported through a European Community Marie Curie Fellowship to Edina Nemeth and Sana Fajdiga.

\section{References}

Bernet-Camard, M.F., Lievin, V., Brassart, D., Neeser, J.R., Servin, A.L., Hudault, S., 1997. The human Lactobacillus acidophilus strain LA1 secretes a nonbacteriocin antibacterial substance(s) active in vitro and in vivo. Applied and Environmental Microbiology 63, 2747-2753.

Brassart, D., Schiffrin, E.J., 1997. The use of probiotics to reinforce mucosal defense mechanisms. Trends in Food Science and Technology 9, 321-326.

Campieri, M., Rizzello, F., Venturi, A., Poggioli, G., Ugolini, F., Helwig, U., Amadini, C., Romboli, E., Gionchetti, P., 2000. Combination of antibiotic and probiotic treatment is efficacious in prophylaxis of postoperative recurrence of Crohn's disease: a randomised controlled study vs mesalamine. Gastroenterology 118, G4179.

Casellas, F., Borruel, N., Papo, M., Guarner, F., Antolin, M., Videla, S., Malagelada, J.R., 1998. Antiinflammatory effects of enterically coated amoxicillinclavulanic acid in active ulcerative colitis. Inflammatory Bowel Disease 4, 1-5.

Coconnier, M.H., Liévin, V., Lorrot, M., Servin, A.L., 2000. Antagonistic activity of Lactobacillus acidophilus LB against intracellular Salmonella enterica serovar Typhimurium infecting human enterocyte-like Caco-2/TC-7 cells. Applied and Environmental Microbiology 66, 1152-1157.

Corsetti, A., Gobbetti, M., Smacchi, E., De Angelis, M., Rossi, J., 1998. Accelerated ripening of Pecorino Umbro cheese. Journal of Dairy Research 65, 631-642.

Franklin, J.G., Sharpe, M.E., 1963. The incidence of bacteria in cheesemilk and Cheddar cheese and their association with flavour. Journal of Dairy Research 30, 87-99.

Fuller, R., 1989. Probiotics in man and animals. Journal of Applied Bacteriology 66, 365-378.

Gionchetti, P., Rizzello, F., Venturi, A., Brigidi, P., Matteuzzi, D., Bazzocchi, G., Poggioli, G., Miglioli, M., Campieri, M., 2000. Oral bacteriotherapy as maintenance treatment in patients with chronic pouchitis: a double-blind, placebo-controlled trial. Gastroenterology 119, 305-309.

Greenberg, D.E., Jiang, Z.D., Steffen, R., Verenker, M.P., DuPont, H.L., 2002. Markers of inflammation in bacterial diarrhea among travelers, with a focus on enteroaggregative Escherichia coli pathogenicity. Journal of Infectious Diseases 185, 944-949.

Harig, J.M., Soergel, K.H., Komorowski, R.A., Wood, C.M., 1989. Treatment of diversion colitis with short chain fatty acid irrigation. New England Journal of Medicine 320, 23-28.

Hata, K., Andoh, A., Sato, H., Araki, Y., Tanaka, M., Tsujikawa, T., Fujiyama, Y., Bamba, T., 2001. Sequential changes in luminal microflora and mucosal cytokine expression during developing of colitis in HLA-B27/beta2- 
microglobulin transgenic rats. Scandinavian Journal of Gastroenterology 36, 1185-1192.

Hecht, G., Savkovic, S.D., 1997. Effector role of epithelia in inflammation: interaction with bacteria. Alimentary Pharmacology and Therapeutics 3, 64-69.

Huang, F.C., Werne, A., Li, Q., Galyov, E.E., Walker, W.A., Cherayil, B.J., 2004. Cooperative interactions between flagellin and SopE2 in the epithelial interleukin-8 response to Salmonella enterica serovar typhimurium infection. Infection and Immunity 72, 5052-5062.

Hudault, S., Liévin, V., Bernet-Camard, M.F., Servin, A.L., 1997. Antagonistic activity exerted in vitro and by Lactobacillus casei (strain GG) against Salmonella typhimurium C5 infection. Applied and Environmental Microbiology 63, 513-518.

Jepson, M.A., Colares-Buzato, C.B., Clark, M.A., Hirst, B.H., Simmons, N.L., 1995. Rapid disruption of epithelial barrier function by Salmonella typhimurium is associated with structural modification of intercellular junctions. Infection and Immunity 63, 356-359.

Jepson, M.A., Lang, T.F., Reed, K.A., Simmons, N.L., 1996. Evidence for a rapid, direct effect on epithelial monolayer integrity and transepithelial transport in response to Salmonella invasion. European Journal of Physiology 432, 225-233.

Klaenhammer, T.R., 1993. Genetics of bacteriocins produced by lactic acid bacteria. FEMS Microbiology Reviews 12, 39-85.

Koninkx, J.F.J.G., 1995. Enterocyte-like Caco-2 cells as a tool to study lectin interaction. In: Pusztai, A., Bardocz, S. (Eds.), Lectins: Biomedical Perspectives. Taylor and Francis, London, pp. 81-101.

Koninkx, J.F.J.G., Hendriks, H.G.C.J.M., van Rossum, J.M.A., van den Ingh, T.S.G.A.M., Mouwen, J.M.V.M., 1992. Interaction of legume lectins with the cellular metabolism of differentiated Caco-2 cells. Gastroenterology 102, 1516-1523.

Lee, C.A., Silva, M., Siber, A.M., Kelly, A.J., Galyov, E., McCormick, B.A., 2000. A secreted Salmonella protein induces a proinflammatory response in epithelial cells, which promotes neutrophil migration. Proceedings of the National Academy of Science USA 97, 12283-12288.

Malago, J.J., Koninkx, J.F.J.G., van Dijk, J.E., 2002. The heat shock response and cytoprotection of the intestinal epithelium. Cell Stress and Chaperones 7, 191-199.

Malago, J.J., Koninkx, J.F.J.G., Ovelgönne, H.H., van Asten, F.J.A.M., Swennenhuis, J.F., van Dijk, J.E., 2003. Expression levels of heat shock proteins in enterocyte-like Caco-2 cells after exposure to Salmonella enteritidis. Cell Stress and Chaperones 8, 194-203.

McCafferty, D.M., Zeitlin, I.J., 1989. Short chain fatty acid-induced colitis in mice. International Journal of Tissue Reactions 11, 165-168.

McCormick, B.A., Parkos, C.A., Colgan, S.P., Carnes, D.K., Madara, J.L., 1998. Apical secretion of a pathogen-elicited epithelial chemoattractant activity in response to surface colonization of intestinal epithelia by Salmonella typhimurium. Journal of Immunology 160, 455-466.

McSweeney, P.L.H., Fox, P.F., Lucey, J.A., Jordan, K.N., Cogan, T.M., 1993. Contribution of the indigenous microflora to the maturation of Cheddar cheese. International Dairy Journal 3, 613-634.

Neish, A.S., Gewirtz, A.T., Zeng, H., Young, A.N., Hobert, M.E., Karmali, V., Rao, A.S., Madara, L., 2000. Prokaryotic regulation of epithelial responses by inhibition of IkappaB-alpha ubiquitination. Science 289, 1560-1563.

O’Morain, C., Segal, A.W., Levi, A.J., 1982. Elemental diet as primary treatment of acute Crohn's disease: a controlled trial. British Medical Journal 288, 1859-1862.

Ovelgönne, J.H., Koninkx, J.F.J.G., Pusztai, A., Bardocz, S., Kok, W., Ewen, S.W., Hendriks, H.G.C.J.M., van Dijk, J.E., 2000. Decreased levels of heat shock proteins in gut epithelial cells after exposure to plant lectins. Gut 46, 679-687.

Oxman, T., Shapira, M., Diver, A., Klein, R., Avazov, N., Rabinowitz, B., 2000. A new method of long-term preventive cardioprotection using Lactobacillus. American Journal of Physiology — Heart and Circulatory Physiology 278, H1717-H1724.

Reid, G., Howard, J., Gan, B.S., 2001. Can bacterial interference prevent infection? Trends in Microbiology 9, 424-428.

Saavedra, J.M., 1995. Microbes to fight microbes: a not so novel approach to controlling diarrheal disease. Journal of Pediatric Gastroenterology and Nutrition 21, 125-129.

Sanders, M.E., 1993. Effect of consumption of lactic cultures on human health. Advances in Food and Nutrition Research 37, 67-130.

Sanderson, I.R., 1997. Diet and gut inflammation. Current Opinion in Gastroenterology 13, 518-524.

Schrezenmeir, J., de Vrese, M., 2001. Probiotics, prebiotics and synbiotics approaching a definition. American Journal of Clinical Nutrition 73, 361s-364s.

Shanahan, F., 2000. Probiotics and inflammatory bowel disease: is there a scientific rationale? Inflammatory Bowel Disease 6, 107-115.

Smith, P.K., Krohn, R.I., Hermanson, G.T., Mallia, A.K., Gartner, F.H., Provenzano, M.D., Fujimoto, E.K., Goeke, N.M., Olson, B.J., Klenk, D.C., 1985. Measurement of protein using bicinchoninic acid. Analytical Biochemistry 159, 76-85.

Sugita, T., Togawa, M., 1994. Efficacy of Lactobacillus preparation biolactis powder in children with rotavirus enteritis. Japanese Journal of Pediatrics 47, 2755-2762.

Wallace, T.D., Bradley, S., Buckley, N.D., Green-Johnson, J.M., 2003. Interactions of lactic acid bacteria with human intestinal epithelial cells: effects on cytokine production. Journal of Food Protection 66, 466-472. 